\title{
The new face of safeguarding and promotion of the intangible cultural heritage in Poland
}

\author{
Multimedia materials published by the Ethnographic Museum in Torun
}

DOI: 10.12775/LL.1.2021.011 | CC BY-ND 3.0 PL

Kuyavia is a historical and ethnographic region located in North Central Poland. Situated on the left bank of the Vistula River, Kuyavia stretches from the Skrwa Lewa River in the South to the Wda River in the North and to the Noteć River and Brdowski Lake in the West. Thanks to their black fertile soils and the production of rapeseed (the oil of which is essential to the local cuisine), the Kuyavian lowlands are known as "the granary of Poland" (Piotrowska, 2010a). However, as noted by Agnieszka Piotrowska (2010a), those geographical and agricultural features count among of the reasons for cultural diversity of the region.

The fertile Kuyavian soil lured German and Dutch settlers whose customs such as conducting marriage divinations on 12 December, the eve of the Feast of Saint Lucy - soon started to seep into the local traditions. This cultural diversity of Kuyavia deepened during the Partitions as the region was divided between Russia and Prussia (Piotrowska, 2010b). Those differences were further reinforced by the existing administrative and parish divisions. Finally, Kuyavian culture has also been strongly influenced by the neighbouring regions, predominantly Greater Poland and Mazovia (Piotrowska, 2010b).

Just like in other regions, Kuyavian folk traditions and customs started to slowly disappear at the turn of the 2oth century. Rapid industrialisation and urbanisation accelerated this process significantly after the Second World War and by the mid 
century there were only a few small areas, mostly rural ones, where the traces of Kuyavian cultural diversity could be found (Piotrowska, 2010b). In the 21st century, the everyday traditions and customs have been relegated to tourist attractions and curios, their roots and significance often lost and forgotten.

In the second decade of the 21st century, the Ethnographic Museum in Torun, in cooperation with Kujawsko-Pomorskie Voivodeship, initiated a project aimed at preserving the intangible cultural heritage of the region in a form that would be appealing to the modern audience. The project resulted in a series of publications which not only showcase Kuyavian traditions and customs, but also present their contemporary incarnations. The publications in question took form of CDs containing films, photographs, and recordings otherwise unavailable to the audience.

Since 2016, the Ethnographic Museum in Torun released five CDs, each devoted to a different aspect of Kuyavian culture, including holiday customs, traditional craft, and cuisine. Published in 2016, the first CD, entitled Shrovetide (Zapusty) Customs: Walking with a Goat in Kuyavia Region, presents the tradition of carolling and well-wishing, as well as its modern continuation. Photographs and films included on the CD come from the archives of the Ethnographic Museum in Torun and the Kujawy and Dobrzyń Land Museum in Włocławek. The CD contains both historical and contemporary accounts of this particular custom - which is still popular in some parts of the region - and uses them to familiarise the audience with that custom while discussing its pre-Christian roots. The collected materials - predominantly films and photographs - present the evolution of the custom, highlighting the changes in the costumes donned by the carollers and their symbolism as well as the reactions of those they visit. Those changes are illustrated by two films included on the CD: Podkoziołek in Kuyavia from 1965 and Walking with a Goat from 2007. Additionally, the modern incarnation of the custom is presented in the form of a film coverage of the Twenty Second Zapusty Groups Procession in Włocławek prepared by the Kujawy and Dobrzyń Land Museum in Włocławek.

The second CD, released in 2017, focuses on Easter customs, especially the socalled "good morning marches" (przywołówki)1. Easter Customs: Przywołówki dyngusowe in Kuyavia contains a wide variety of iconographic and audiovisual materials from the collections of numerous cultural institutions such as the Oskar Kolberg Museum in Przysucha, the City Public Library in Inowrocław, the Jan Kasprowicz Museum in Inowrocław and the Polish Radio PiK Archive. The materials - films, photographs, radio broadcasts, and recordings - depict a unique custom which takes place in Szymborz, a district of Inowrocław, and is organised by the members of the Bachelors' Club Association established in the mid-183os. The CD includes texts (edited by Hanna Łopatyńska) describing the custom both from historical and contemporary perspective. The phenomenon of przywołówki and its evolution is also depicted through maps, examples of przywotówki, photographs and scans of the 'protocols' and 'rules' ensuring the correct and efficient conduct of the custom, as well as recordings.

1 Przywołówki is a custom unique to the Kuyavian region. On Easter Sunday young men would climb the highest tree in the area - or a roof - and shout out the names of the girls, announcing how much water they were going to use on them. Finally, they would announce the name of the man visiting each girl the next day. 
The third CD, released in 2018, presents Kuyavian sand pattern sprinkling, a traditional method of decorating rooms and yards. The CD contains not only historical photographs and films from the archives of the Ethnographic Museum in Torun and the Kujawy and Dobrzyń Land Museum in Włocławek, but also records of contemporary recreations of this tradition, taken during the festival organised by the Ethnographic Museum in Torun and the competition in Przedacz (both of them took place in 2017). The materials collected on the CD discuss the origins of sand sprinkling, the evolution of the custom and the materials used; additionally the most popular patterns are presented and their symbolism is explained. The inclusion of both archival materials - especially films from folklore festivals in the 1970 - and contemporary ones serves to show that the visual appeal of the art of sand sprinkling still attracts the attention of the audiences, connecting the past and present.

The fourth CD, published in 2019, is devoted to Kuyavian embroidery, known for its simple patterns and the use of white thread. Materials on the CD include photographs and scans of patterns, stiches, and motifs characteristic for Kuyavian embroidery from the archives of the Ethnographic Museum in Torun and the Kujawy and Dobrzyń Land Museum in Włocławek, as well as private collections. The $\mathrm{CD}$ also contains recordings of performances of kujawiak, a regional dance. The materials included on the CD not only present the history of Kuyavian embroidery and its unique features but also discuss the whole process in detail, starting from the choice of materials, through the choice and transfer of pattern, to its implementation. What is also important, the contents of the CD are selected to additionally serve as a tutorial for all those who want to learn this particular style of embroidery, seeing as it contains patterns as well as information about motifs and stitches.

The latest CD, released in $\mathbf{2 0 2 0}$, discusses making plum jam in a traditional way. The CD contains photographs and scans from the archives of the Ethnographic Museum in Torun, the Society of Friends of Lower Vistula Valley, the National Museum of Agriculture and Agro-Food Industry in Szreniawa of the Polish Chamber of Traditional and Local Products as well as from the private collections. The materials also include a film - entitled Making Plum Jam in a Traditional Way - showing the whole process and history of making jam in Kuyavia. Apart from discussing the history of the cultivation of plums and the tradition of plum jam making in the Lower Vistula Valley, the CD serves also as a recipe book as it contains both traditional recipes and their contemporary incarnations.

It is impossible to deny the value of the CDs published as a part of Intangible Cultural Heritage in Kujawsko-Pomorskie Voivodeship project. The publications are not merely encyclopaedic compendiums of cultural knowledge, but, what is more important, ensure both the preservation and continuation of those customs and traditions, encouraging the audience to recreate them in their own communities. Furthermore, the materials are presented in a visually appealing way, a quality which will certainly attract the attention of people of all ages. Another feature of the publication which deservers the praise and acknowledgement is the wide variety of materials - both historical and contemporary - included on the CDs: the assortment of photographs, films, radio broadcasts, scans of documents, and audio 
recordings from different decades shows the audience not only the prevalence of those regional customs, but also their relevance in present times. However, the most admirable aspect of the whole publication is the fact that the CDs are available for free - for educational purposes - to both individuals and institutions popularising traditional culture. The only criticism of the series could be that the format in which the materials are presented - digital optical discs - may be problematic to access. It is important to keep in mind that modern laptops mostly do not have CD/DVD drives and older models may have problem with reading the CD itself. Hence, it would be a good idea to make the materials available online as well. $\mathrm{Ne}-$ vertheless, despite this one minor point of criticism, the value of the publication is undisputable - it not only reminds the audiences about the cultural uniqueness of the region, but also encourages them to continue those traditions.

\section{REFERENCES}

Czachowski, H. (ed.) (2018). Kuyavian Sand Pattern Sprinkling. Toruń: Muzeum Etnograficzne im. Marii Znamierowskiej-Prüfferowej w Toruniu.

Czachowski, H., Słomska-Nowak J. (eds.) (2019). Kuyavian Embroidery. Toruń: Muzeum Etnograficzne im. Marii Znamierowskiej-Prüfferowej w Toruniu.

Czachowski, H., Słomska-Nowak J. (eds.) (2020). Making Plum Jam in a Traditional Way. Torun: Muzeum Etnograficzne im. Marii Znamierowskiej-Prüfferowej w Toruniu.

Łopatyńska, H. (ed.) (2016). Shrovetide (Zapusty) Customs: Walking with a Goat in Kuyavia Region. Toruń: Muzeum Etnograficzne im. Marii Znamierowskiej-Prüfferowej w Toruniu.

Łopatyńska, H. (ed.) (2017). Easter Customs: Przywołówki dyngusowe in Kuyavia. Toruń: Muzeum Etnograficzne im. Marii Znamierowskiej-Prüfferowej w Toruniu.

Piotrowska, A. (2010a). Geografia regionu. In: Dialekty i gwary polskie. Kompendium internetowe. Retrieved from: http://www.dialektologia.uw.edu.pl/index.php? $l_{1}=$ mapa-serwisu $\& l_{2}=\& l_{3}=\& l_{4}=$ kujawygeografia-regionu

Piotrowska, Agnieszka. 201ob. Kultura ludowa. In: Dialekty i gwary polskie. Kompendium internetowe. Retrieved from: http://www.dialektologia.uw.edu.pl/index.php?l1=opis-dialektow \&l2=dialektwielkopolski\&l $3=$ kujawy\&l $4=$ kujawy-kultura2 